\begin{tabular}{|c|c|c|}
\hline \multirow{2}{*}{ DVल } & $\begin{array}{l}\text { International Journal of Current Research in } \\
\text { Biosciences and Plant Biology }\end{array}$ & $=0$ \\
\hline & Volume $4 \bullet$ Number 1 (January-2017) • ISSN: 2349-8080 (Online) & \\
\hline $\begin{array}{l}\text { EXCELLENT } \\
\text { PUBLISHERS }\end{array}$ & Journal homepage: www.ijcrbp.com & wawe.jictop com \\
\hline
\end{tabular}

\title{
In Vitro Evaluation of Nutrient Content of Asian Palmyra Palm's (Borassus flabellifer L.) Husk Fermented with EM-4 for Beef Cattle Feed
}

\author{
Dwi Nur Aini Dahlan and Khusnul Khotimah*
}

Lecturer Staff, Teacher Training Science Program, Biology, Samarinda 75251, East Kalimantan, Indonesia

*Corresponding author.

\begin{tabular}{|c|c|}
\hline Abstract & Article Info \\
\hline $\begin{array}{l}\text { Beef cattle livestock production that affects domestic meat needs is highly determined by } \\
\text { meeting feed needs. However, the production is often hampered by continuity and feed } \\
\text { cost issues. The husk of Asian Palmyra palm contains high nutrient and can be used as } \\
\text { alternative feed. The husk is first fermented with EM-4 to improve its nutrient content. } \\
\text { Husk's potency as livestock feed can be determined by measuring its nutrient, } \\
\text { digestibility, and total digestible nutrient TDN value in vitro. This study aimed to } \\
\text { determine the effect of in vitro treatment using Asian Palmyra palm fermented with EM-4 } \\
\text { on its nutrient content (dry matter-DM, organic matter-OM, crude protein-CP, crude fiber- } \\
\text { CF, and crude fat) when it is fed to beef cattle. This experimental quantitative study used } \\
\text { Complete Randomized Design (CRD) with } 5 \text { treatments and } 3 \text { replications. Treatment was } \\
\text { differenced by the concentration of EM-4 as fermenter on the husk of Asian Palmyra } \\
\text { palm, i.e. 0\% (PO); 0.1\% (P1); 1\% (P2); } 5 \% \text { (P3); and } 10 \% \text { (P4). Parameters observed on } \\
\text { nutrient content were among other dry matter (DM), organic matter (OM), crude protein } \\
\text { (CP), crude fiber (CF), and crude fat following Association of Official Analytical } \\
\text { Chemists-AOAC (1980). To determine the influence, proximate analysis and statistical } \\
\text { analysis using One Way ANOVA were employed, followed with } 5 \% \text { Least Significant } \\
\text { Difference (LSD) test when significant influence was found. Study result indicated that } \\
\text { using husk waste from Asian Palmyra palm (P<0.05) significantly affects nutrient content } \\
\text { (DM, OM, CP, CF, and crude fat). Average } 1 \% \text { EM-4 in the husk of Asian Palmyra palm } \\
\text { is already capable of improving nutrient content (DM, OM, CP, CF, and crude fat). }\end{array}$ & $\begin{array}{l}\text { Keywords } \\
\text { Asian Palmyra palm } \\
\text { Proximate analysis } \\
\text { Ruminants }\end{array}$ \\
\hline
\end{tabular}

\section{Introduction}

Cattle livestock, particularly beef cattle, is one of meatproducing resources which have high economic value and high importance in community (Mustofa et al., 2015). Main issues affecting cattle livestock production are among other continuity and feed cost. Therefore, it is necessary to carry out efforts to make feed cost, such as agriculture waste, efficient. Rahmanto (2011) stated that waste use is one of the alternatives to improve the economic value of the waste. Waste use as livestock feed has previously been performed by Parulin (2009) who used oil palm fronds and industrial waste. It is presumed that Asian Palmyra palm which has close relationship with oil palm also is a potential cattle livestock feed. According to Assessment Institute for 
Agricultural Technology (BPTP) in ISBN 978-9793112-32-9 (2010), livestock feed materials usually contain nutrients comprise of water, minerals, proteins, fats, carbohydrates, and vitamins. Hariyanto (2012) reported that ruminant nutrient provides stronger foundation in developing feed formula to meet livestock need in accordance with their genetic potential and physiological status to survive and normally reproduce.

Nutrient need increases during growth and fattening phases. According to Assessment Institute for Agricultural Technology (BPTP) in ISBN 978-9793112-32-9 (2010), beef cattle feed during fattening phase (7 months) requires nutrient content with $\mathrm{DM}>88 \%, \mathrm{CP}>12 \%$, crude fat $<6 \%, \mathrm{CF} 12-17 \%$, TDN $>$ $64 \%$, and ash < 10\%. In addition, Wahyudi and Bambang (2002) stated that in dry condition the husk of Asian Palmyra palm contains $5.942 \%$ cellulose, $0.144 \%$ water, and $5.268 \%$ ash. However, it is necessary to have more detailed information on the content of Asian Palmyra palm to improve its nutrient. In addition, chopping and grinding combined with biological treatment through fermentation are also necessary.

Livestock feed fermentation is carried out to meet 3 purposes, i.e. to preserve feed to make it stays in good condition when needed, to improve the nutrient value of the material, and to improve digestibility (Zhang et al., 2012). According to Javaid and Bajwa (2011), EM-4 is a mix of fermentation bacteria from genus Lactobacillus, Actinomycetes, photosynthetic bacteria and yeast. EM-4 in livestock feed will improve the composition of microorganisms that can help feeds easier to digest by livestock.

Basing on the ideas above, it is necessary to carry out study on the potency of Asian Palmyra palm's husk waste as livestock feed after being treated with and without EM-4. One of the methods used to determine the nutrient content of Asian Palmyra palm's husk waste is proximate analysis following AOAC (1980).

\section{Materials and methods}

\section{Fermentation of Asian Palmyra palm}

The husk of Asian Palmyra palm was chopped to obtain $1-5 \mathrm{~cm}$ as the smallest size prior to being put in $60^{\circ} \mathrm{C}$ oven for 14 hours. A total of 100 grams husk was weighed and put into plastic bag. EM-4 was then put in accordance with the treatments and distilled water of
$30 \%$ of sample weight was added. The mix was stirred evenly prior to incubation for 7 days.

\section{Retrieving rumen fluid}

Boiled water was put into water flask and discarded. Syringe hose was then put into rumen through modified cattle stomach and immediately put into the empty flask. The fluid was then filtered using filter cloth prior mixing with buffer solution.

\section{Proximate analysis following AOAC (1980)}

Determining DM concentration: Porcelain dish was heated in $105^{\circ} \mathrm{C}$ oven for $1 \mathrm{hr}$ prior to being put in exsiccator for $1 \mathrm{hr}$ and weighed (A g). The dish was then added with $5 \mathrm{~g}$ sample and re-weighed (B $\mathrm{g}$ ) prior to being put in exsiccator for 1 hour and re-weighing $(\mathrm{C} \mathrm{g})$.

$$
D M=\frac{C-A}{B-A} X 100 \%
$$

Determining OM concentration: Porcelain dish was put into $550^{\circ} \mathrm{C}$ furnace for $4 \mathrm{hrs}$ prior to being put in exsiccator for $1 \mathrm{hr}$ and re-weighing (D g).

$$
\begin{gathered}
\text { Ash }=\frac{D-A}{2 B-A} X 100 \% \\
\mathrm{OM}=100 \%-\mathrm{ash}
\end{gathered}
$$

Determining CP concentration: Greaseproof paper was weighed (A g) and $3 \mathrm{~g}$ sample was put onto the paper prior to re-weighing (B g). Sample was then put into Kjeldahl flask and $1.4 \mathrm{~g}$ catalysator (Kjeldahl table) and boiling stone were added. A total of $5 \mathrm{~mL}$ concentrated hydrogen peroxide with dispenser was then added prior to destruction until clear green. A total of $60 \mathrm{~mL}$ distilled water (divided into four) was then added prior to stirring and being put into Erlenmeyer flask. A total of $25 \mathrm{~mL} 40 \% \mathrm{NaOH}$ was then added into the Erlenmeyer flask prior to distillation with beaker glass containing $25 \mathrm{~mL} 0.1 \quad \mathrm{~N} \mathrm{H}_{2} \mathrm{SO}_{4}$ and max 3 drops indicator as the receiving end. The beaker glass was then titrated using $0.1 \mathrm{~N} \mathrm{NaOH}$ until the solution color become clear and the titration volume was measured $(\mathrm{C}$ $\mathrm{mL}$ ). Blank solution was made by performing titration on the beaker glass containing $25 \mathrm{~mL} \mathrm{H}_{2} \mathrm{SO}_{4}$ and max 3 drops indicator prior to measurement of the titration volume (D g). 


$$
C P=\frac{(D-C) \times 0.1 \times 0.014 X 6.25}{B-A} \times 100 \%
$$

Determining crude fiber, $C F$ : Grease proof paper was weighed (A g) and $1 \mathrm{~g}$ sample was put onto the paper prior to re-weighing (B g). Sample was then put into measuring cylinder for $\mathrm{CF}$ analysis and $50 \mathrm{~mL} 0.3 \mathrm{~N}$ $\mathrm{H}_{2} \mathrm{SO}_{4}$ was added using measuring cylinder prior to boiling for 30 minutes. A total of $25 \mathrm{~mL} 1.5 \mathrm{~N} \mathrm{NaOH}$ was then quickly added prior to boiling for 25 minutes. A total of $0.5 \mathrm{~g}$ EDTA was then quickly added prior to re-boiling for 25 minutes. Sand was first put in filtration dish and measuring cylinder was taken out from boiling equipment prior to rinsing using hot distilled water until all solution were in filtration dish. A total of $50 \mathrm{~mL} 0.3$ $\mathrm{N} \mathrm{HCl}$ was then added and allowed to stay for 1 minute prior to being sucked using vacuum pump.

Acetone was then added and allowed to stay for 1 minute prior to being sucked until dry. The sample was then put in $140^{\circ} \mathrm{C}$ oven for $1.5 \mathrm{hr}$ prior to being put in exsiccation for $1 \mathrm{hr}$ and weighing $(\mathrm{Cg})$. The sample was put in $550^{\circ} \mathrm{C}$ furnace for $2 \mathrm{hrs}$ prior to being put again in exsiccator for $1 \mathrm{hr}$ and weighing (D g).

$$
C F=\frac{(C-D)}{B-A} X 100 \%
$$

Determining crude fat: Measuring cylinder, containing 2-3 boiling stones, was put into $105^{\circ} \mathrm{C}$ oven for $1 \mathrm{hr}$ prior to being put in exsiccator for $1 \mathrm{hr}$. Ash-free filter paper was weighed (A g) and 3-5 g sample was added prior to re-weighing (B g). Sample was then wrapped using the filter paper prior to being put in porcelain dish. Measuring cylinder special for fat analysis was taken out from exsiccator and weighed $(\mathrm{Cg})$ prior to filling beaker glass with $50 \mathrm{~mL}$ n-hexane using measuring cylinder. The cylinder and porcelain tool were then installed onto Goldfish extraction apparatus and extraction was performed for 4 hrs. Porcelain tool was taken out with flask special to collect hexane until only small amount of hexane left in the beaker glass. Measuring cylinder containing fats was then put into $80^{\circ} \mathrm{C}$ vacuum oven and air was sucked from the oven for $1.5 \mathrm{hr}$. Measuring cylinder was then put into exsiccator for $1 \mathrm{hr}$ and reweighed (D g).

$$
\text { Crude Fat }=\frac{D-C}{B-A} X 100 \%
$$

\section{Data analysis}

This experimental laboratories study used $5 \times 3$ Complete Randomized Design (CRD) (5 treatments and 3 replications), followed with 5\% Least Significant Difference (LSD) test when significant influence was found.

\section{Results and discussion}

Effect of EM-4 treatment on the dry matters (DM) and organic matters $(\mathrm{OM})$ of the husk of Asian Palmyra palm

Study result indicates that treatment using EM-4 significantly influenced the DM of the husk $(p<0.05)$. According to 5\% LSD test, there was no significant difference between control added with $0.1 \%$ EM-4 and added with $1 \%$ EM-4. However, highly significant difference was found between treatment with 5\% EM-4 and 10\% EM-4 (Table 1).

Table 1. Summary of 5\% LSD test on the effect of EM-4 on the dry matters (DM) of Asian Palmyra palm's husk.

\begin{tabular}{lll}
\hline Treatment & Mean \pm SD & Notation \\
\hline P0 0\% & $90.05 \% \pm 0.51003$ & $\mathrm{a}$ \\
PI 0.1\% & $91.1 \% \pm 1.07258$ & $\mathrm{ab}$ \\
PII 1\% & $91.455 \% \pm 0.36116$ & $\mathrm{abc}$ \\
PIII 5\% & $92.32 \% \pm 1.17843$ & $\mathrm{bc}$ \\
PIV 10\% & $92.66 \% \pm 0.05132$ & $\mathrm{C}$ \\
\hline
\end{tabular}

Note: Figures with same letter indicate no significant difference according to 5\% LSD test.

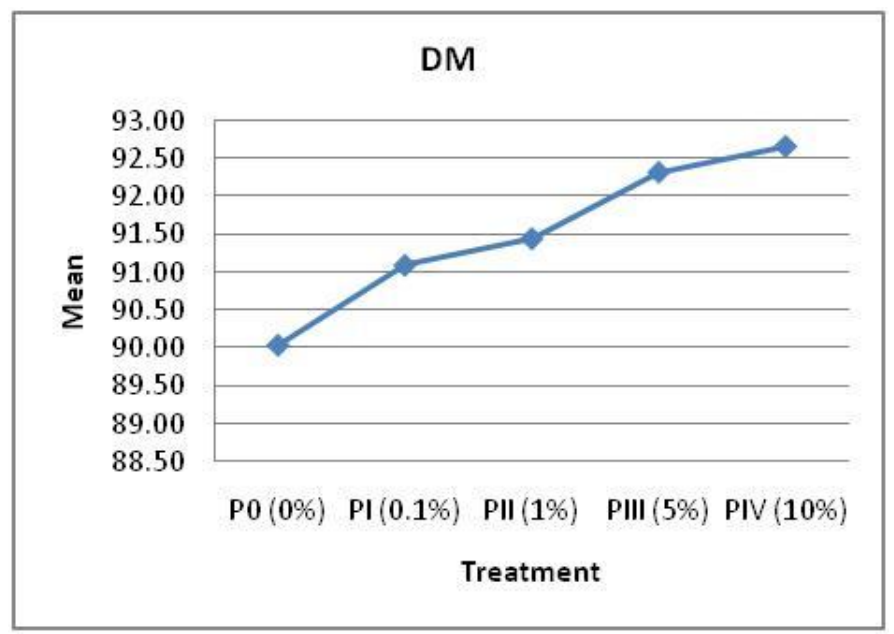

Fig. 1: Mean Dry Matters (DM) content.

The DM of the husk increased along with increasing EM-4 dosage (Fig. 1). The fourth treatment (10\% 
EM-4), as the highest dosage, showed the highest DM $(92.66 \%)$, followed by the third (5\% EM-4), second (1\% EM-4), and first (0.1\% EM-4) treatments with DM content of $92.32 \%, 91.45 \%$, and $91.1 \%$, respectively. According to Assessment Institute for Agricultural Technology (BPTP; ISBN 978-979-3112-32-9; 2010), beef cattle feed during fattening phase ( 7 months) requires nutrient content with $88 \% \mathrm{DM}$, meaning feed without EM-4 is capable of meeting cattle's need. Decrease in water content not only capable of increasing the DM of the husk but also influencing Organic Matters $(\mathrm{OM})$ where increase in DM decreases OM.

According to statistic test on Organic Matters (OM), significant influence due to EM-4 treatment $(p>0.05)$ was found, and 5\% LSD test showed that there was a highly significant difference between treatment and control. OM content decreased along with increasing EM-4 dosage (Table 2). The highest OM content $(94.74 \%)$ belonged to 0 treatment (control), followed by first $(0.1 \%$ EM-4), second (1\% EM-4), third (5\% EM-4), and fourth (10\% EM-4) treatments with OM content of $93.54 \%, 91.26 \%$, $83.9 \%$, and $76.54 \%$, respectively (Fig. 2).

Table 2. Summary of 5\% LSD test on the effect of EM-4 on the organic matters (OM) of Asian Palmyra palm's husk.

\begin{tabular}{lll}
\hline Treatment & Mean \pm SD & Notation \\
\hline P0 0\% & $94.75 \% \pm 0.09238$ & $\mathrm{a}$ \\
PI 0.1\% & $93.54 \% \pm 0.18930$ & $\mathrm{~b}$ \\
PII 1\% & $91.26 \% \pm 0.36364$ & $\mathrm{c}$ \\
PIII 5\% & $83.91 \% \pm 2.32987$ & $\mathrm{~cd}$ \\
PIV 10\% & $76.54 \% \pm 1.93412$ & $\mathrm{D}$ \\
\hline
\end{tabular}

Note: Figures with same letter indicate no significant difference according to 5\% LSD test.

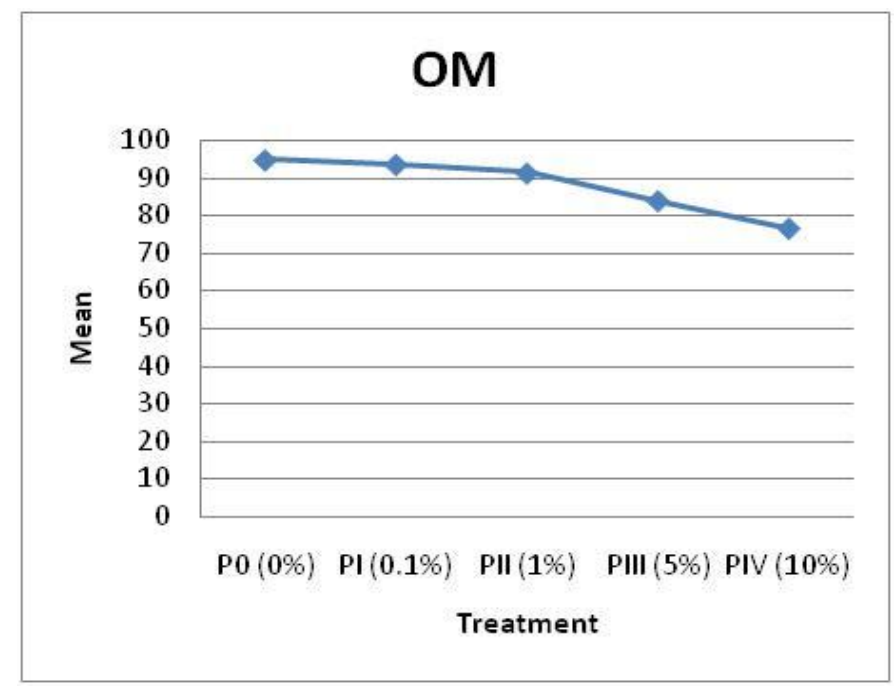

Fig. 2: Mean Organic Matters (OM) content.
OM decreased because it is the main source for energy, growth, and cellular repair for important microorganism such as mold, yeast, and Lactobacillus in EM-4 (Smith et al., 1978). Arief et al. (2008) stated that nutrient source from OM added with high microorganism counts lead to high microorganism activity. According to Dewi et al. (2006), in addition to water in the growth media, mold also requires other components such OM, carbon source, nitrogen source and growth factor.

\section{Effect of EM-4 treatment on the crude protein (CP) of the husk of Asian Palmyra palm}

According to this study and statistic test on crude protein $(\mathrm{CP})$, significant influence due to EM-4 treatment $(p<0.05)$ on CP content of the husk was found, and 5\% LSD test showed that significant difference was yet to find between $0.1 \%$ EM-4 treatment and control. However, highly significant difference was found between control and 1\%,5\%, and 10\% EM-4 treatments (Table 3).

Table 3. Summary of 5\% LSD test on the effect of EM-4 on the crude protein (CP) of Asian Palmyra palm's husk.

\begin{tabular}{lll}
\hline Treatment & Mean \pm SD & Notation \\
\hline P0 0\% & $5.95 \% \pm 1.10693$ & a \\
PI 0.1\% & $8.28 \% \pm 1.59800$ & a \\
PII 1\% & $10.25 \% \pm 0.62554$ & b \\
PIII 5\% & $13.04 \% \pm 1.57068$ & c \\
PIV 10\% & $16.9 \% \pm 0.8167$ & D \\
\hline
\end{tabular}

Note: Figures with same letter indicate no significant difference according to 5\% LSD test.

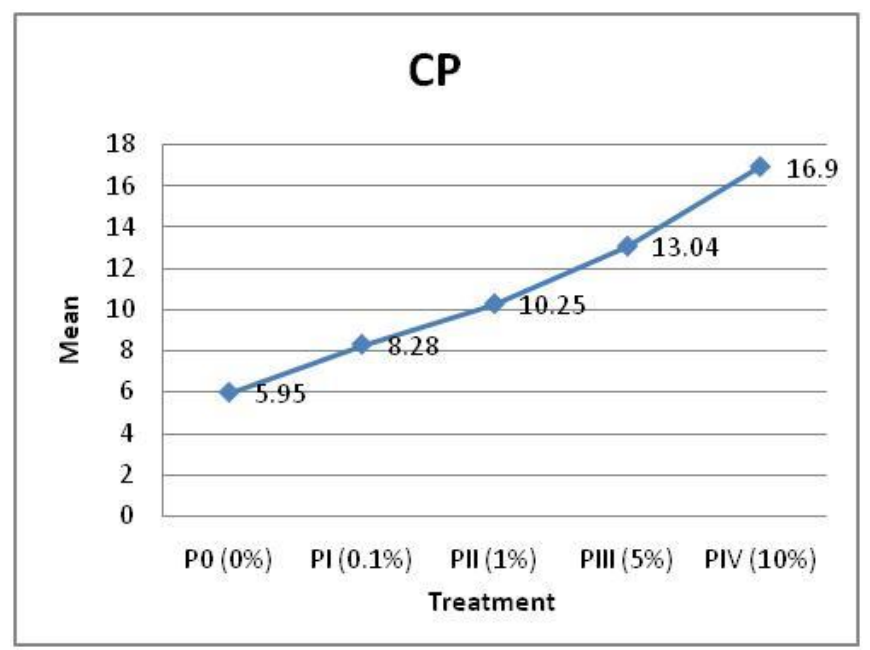

Fig. 3: Mean Crude Protein (CP) content.

CP content increased along with increasing EM-4 dosage (Fig. 3). The lowest CP content (5.95\%) 
belonged to 0 treatment (control), followed by first (0.1\% EM-4), second (1\% EM-4), third (5\% EM-4), and fourth (10\% EM-4) treatments with CP content of $8.28 \%, 10.25 \%, 13.04 \%$, and $16.9 \%$, respectively. According to Assessment Institute for Agricultural Technology (BPTP; ISBN 978-979-3112-32-9; 2010), beef cattle feed during fattening phase ( 7 months) requires nutrient content with $12.7 \% \mathrm{CP}$, meaning $5 \%$ EM-4 treatment is capable of meeting cattle's need.

CP content increased presumably due to other nutrients decreasing, particularly carbohydrates which were used by the microbes to grow and develop such as Lactobacillus in EM-4 which played important role fermenting organic matters $(\mathrm{OM})$ to produce lactate acid. Lactobacillus growth is highly supported by other contents in the growth media such as water, where the microbe is made up of a single protein (Mathews et al., 2000). According to Mirwandhono et al. (2006), increasing CP is presumably because of mold. During mold fermentation process, carbohydrates (nitrogen-free extract) are broken down into glucose units. Glucose is needed by mold as precursor for formation of pyruvate acid that will produce ATP. In addition, glucose also needed as carbon source for microbes in EM-4.

\section{Effect of EM-4 treatment on the crude fiber (CF) of the husk of Asian Palmyra palm}

According to this study and statistic test on crude fiber (CP), significant influence due to EM-4 treatment $(p<0.05)$ on $\mathrm{CF}$ content of the husk was found, and $5 \%$ LSD test showed that all EM-4 treatments $(0.1 \%$ to $10 \%$ ) already showed highly significant difference with control (Table 4).

CF content mostly increased along with increasing EM4 dosage as shown by 0 treatment control) with CF of $23.53 \%$, followed by increase on first treatment $(0.1 \%$ EM-4) (28.94\%) and second treatment (1\% EM-4) $(30.14 \%)$. Such increases were followed by slight decrease on third treatment (5\% EM-4) $(28.94 \%)$ and the highest CF content on fourth treatment (10\% EM-4) (31.47\%) (Fig. 4).

According to Assessment Institute for Agricultural Technology (BPTP) in ISBN 978-979-3112-32-9 (2010), beef cattle feed during fattening phase ( 7 months) requires $18.4 \% \mathrm{CF}$, meaning even without EM-4 treatment the feed is already capable of meeting cattle's need.
Table 4. Summary of 5\% LSD test on the effect of EM-4 on the crude fiber (CF) of Asian Palmyra palm's husk.

\begin{tabular}{lll}
\hline Treatment & Mean \pm SD & Notation \\
\hline P0 0\% & $23.53 \% \pm 0.10504$ & $\mathrm{a}$ \\
PI 0.1\% & $29.68 \% \pm 0.16862$ & $\mathrm{~b}$ \\
PII 1\% & $30.14 \% \pm 0.4041$ & $\mathrm{bc}$ \\
PIII 5\% & $28.94 \% \pm 1.21540$ & $\mathrm{c}$ \\
PIV 10\% & $31.47 \% \pm 0.11533$ & $\mathrm{~d}$ \\
\hline
\end{tabular}

Note: Figures with same letter indicate no significant difference according to 5\% LSD test.

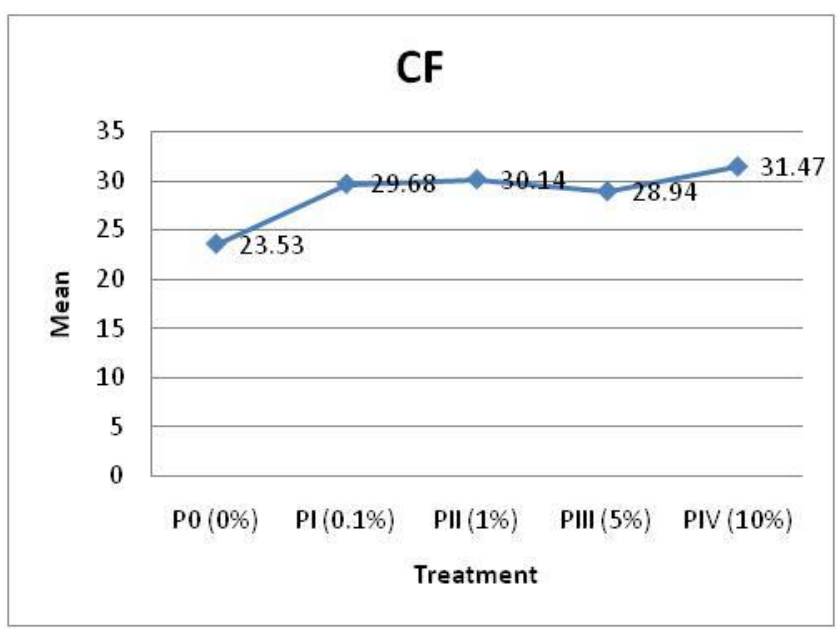

Fig. 4: Mean Crude Fiber (CF) content.

\section{Effect of EM-4 treatment on the crude fat of the husk of Asian Palmyra palm}

According to the last proximate analysis on measurement data of Crude Fat of the husk along with statistic test, significant influence due to EM-4 treatment $(p>0.05)$ on Crude Fat was not found. In addition, 5\% LSD test showed that significant difference was yet to find between control and $0.1 \%$ and $1 \%$ EM-4 treatments. However, highly significant difference was found between control and 5\% and 10\% EM-4 treatments (Table 5).

The highest crude fat content was found in 0 treatment (control), i.e. $1.04 \%$, followed by first $(0.1 \%$ EM-4), second (1\% EM-4), third (5\% EM-4), and fourth (10\% EM-4) treatments with crude fat content of $1.02 \%$, $1.01 \%, 0.92 \%$, and $0.91 \%$, respectively (Fig. 5). According to Assessment Institute for Agricultural Technology (BPTP; ISBN 978-979-3112-32-9; 2010), beef cattle feed during fattening phase ( 7 months) requires nutrient content with 3\% Crude Fat, meaning feed without EM-4 treatment is capable of meeting cattle's need. From all the data obtained, it is known that increasing EM-4 dosage decreases crude fat content. 
Sari et al. (2015) stated that decreasing Crude Fat is presumably because of fat breakdown by yeast's lipolytic enzyme. Pratiwi et al. (2008) stated that during fermentation process, fat in the husk of Asian Palmyra palm decreases due to fat degradation into fatty acids by lipase enzyme that naturally presents in feed materials or is naturally produced by microorganisms growing in fermented feed materials such as lipolytic bacteria (e.g. Pseudomonas, Alcaligenes, Serratia and Micrococcus). Such bacteria also belong to halophilic group. Fats are broke down into volatile and non-volatile fatty acids that will produce aroma and taste.

Table 5. Summary of 5\% LSD test on the effect of EM-4 on the crude fat of Asian Palmyra palm's husk

\begin{tabular}{lll}
\hline Treatment & Mean \pm SD & Notation \\
\hline P0 0\% & $1.04 \% \pm 0.01528$ & $\mathrm{a}$ \\
PI 0.1\% & $1.02 \% \pm 0.04933$ & $\mathrm{ab}$ \\
PII 1\% & $1.01 \% \pm 0.07000$ & $\mathrm{abc}$ \\
PIII 5\% & $0.92 \% \pm 0.01528$ & $\mathrm{bc}$ \\
PIV $10 \%$ & $0.91 \% \pm 0.08505$ & $\mathrm{c}$ \\
\hline
\end{tabular}

Note: Figures with same letter indicate no significant difference according to 5\% LSD test.

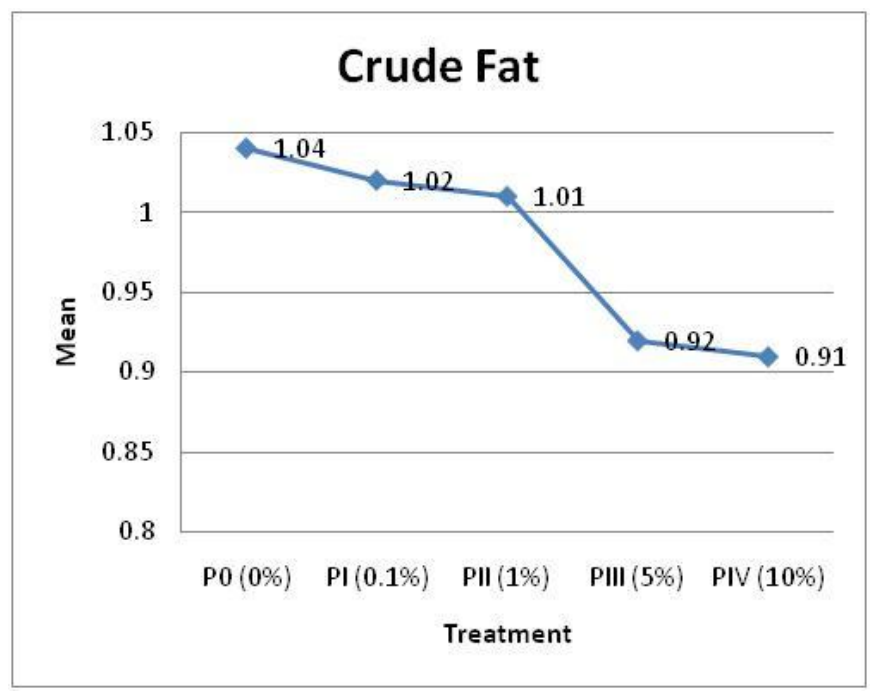

Fig. 5: Mean Dry Matters (DM) content.

\section{Conclusion}

Non-fermented husk of Asian Palmyra palm can be used as 7 month beef cattle feed during fattening phase with body weight of around $100-150 \mathrm{~kg}$. The use of the husk fermented with EM-4 $(p<0.5)$ significantly influenced nutrient contents (DM, OM, CP, CF, and crude fat). Asian Palmyra palm husk treated with 1\% EM-4 was averagely already capable of improving the husk nutrient contents (DM, OM, CP, CF and crude fat).

\section{Conflict of interest statement}

Authors declare that they have no conflict of interest.

\section{References}

Arif, M., Kusumaningsih, M., Rahardja, B.S., 2008. Kandungan protein kasardan serat kasarpada pakan buatan yang difermentasidengan probiotik. J. Ilmiah Perikanandan Kelautan. 3(2), 1-4

Association of Official Analytical Chemists, [AOAC] 2005. Official Methodesof Analysis $13^{\text {th }}$ Edn. AOAC, Washington DC.

Dewi, A. K., Utama, C. S., Mukodiningsih, S., 2014. Fungi's total content, type of molds and yeasts on waste feed mill with various levels of 'starfung' starter. Agripet. 14(2), 102-106.

Hariyanto, B., 2012. Perkembangan penelitian nutrisi ruminansia. Wartazoa. 22(4), 170-177.

Javaid, A., Bajwa, R., 2011. Field evaluation of effective microorganisms (EM) application for growth, nodulation, and nutrition of mung bean. Tubitak. 35, 443-452.

Mathews, C. K., Holde., Ahern, K. G., 2000. Biochemistry $3^{\text {th }}$. Addition Wesley Longman, Inc., San Francisco.

Miwandhono, E., Bachari, I., Sitomorung., 2006. Nutrient value test of cassava tuber skin fermented by Aspergillus niger. J. Agribisnis Perternakan. 2(3), 91-95.

Mustofa, A. N., Wahyuningsih, D., Muhammad, A., 2015. Analisis faktor yang mempengaruhi pengambilan keputusan peternakandalam memulai usaha ternak sapo potong desa kedungkumpul kecamatan sarirejo kabupaten lamongan. J. Ternak. 6(1), 3-8.

Parulin, T., 2009. Efek Pelepahdaun Kelapa Sawitdan Limbah Industrinyasebagai Pakanterhadap Pertumbuhan Sapi Peranakan Ongolepada Fase Pertumbuhan. Thesis. North Sumatera, Faculty of Agriculture, North Sumatera University.

Pratiwi, W., Erriza, A., Melati. 2008. Fermentasi Tepung Dedak Menggunakan Ragi Tape untuk Meningkatkan Nutrisi Pakan Ikan. PKM, IPB Press, Bogor.

Rahmanto, M. I., 2011. Identifikasi potensi pemanfaat limbah pertanian di kabupaten bekasi. J. Agribisnis Pengembangan Wilayah. 2(2), 36-50.

Sari, M. L., Ali, A. I. M., Sandi.S., Yolanda, A., 2015. Kualitas serat, lemakKasar, dan BETN terhadap lama penyimpanan wafer rumput kumpai 
Minyakdengan Perekat Keragaman. 4(2), 35-40.

Smith, O. B., Macleod, G. K., Mowat, D. N., Fox, C. A and Moran, E.T. 1978. Performance and health of calves fed wet caged layer excreta as a protein supplement. J. Anim. Sci. 47(4), 833-842.

South Kalimantan Assessment Institute for Agricultural Technology [BPTP]. 2010. ISBN 978-979-3112-329 tentang Budidaya Sapi Potong. BPTP: South Kalimantan.
Suparjo., 2010. Analisis Bahan Pakan Secara Kimiawi: Analisis Proksimatdan Analisis Serat. Faculty of Animal Sciences, Jambi University Press, Jambi.

Wahyudi.,Bambang., 2002. Pembuatan etanoldari sabut buah siwalandengan proses hidrolisis fermentasi. J. Kimia Teknol. 3(2), 240-247.

Zhang, S., Hu, X., Ma, J., Ma, Z., Liu, X., Cui, L., 2012. Study on feed fermented from seaweed waste. J. Microbiol. 6(50), 7610-7615.

\section{How to cite this article:}

Dahlan, D.N.A., Khotimah, K., 2017. In vitro evaluation of nutrient content of Asian Palmyra palm's (Borassus flabellifer L.) husk fermented with EM-4 for beef cattle feed. Int. J. Curr. Res. Biosci. Plant Biol. 4(1), 13-19.

doi: http://dx.doi.org/10.20546/ijcrbp.2017.401.003 